\title{
Lasten ja nuorten luontoyhteyden vahvistamisesta perusta tulevaisuuden lähimatkailulle
}

Outi Rantala, Lapin yliopisto, Matkailualan tutkimus- ja koulutusinstituutti (MTI) Riikka Puhakka, Helsingin yliopisto, Bio- ja ympäristötieteellinen tiedekunta, Ekosysteemit ja ympäristö -tutkimusohjelma

Globaalin ilmastokriisin vuoksi lähimatkailun mahdollisuuksien huomioimisesta on tulossa yksi keino, jolla matkailusta voidaan tehdä entistä vastuullisempaa. Suomessa on pitkät perinteet lähimatkailuun erityisesti luonnossa liikkumisen muodossa - lähiluonnossa on liikuttu esimerkiksi retkeillen, marjastaen ja luontoa havainnoiden (ks. Sievänen \& Neuvonen, 2011). Kaupungistuneessa yhteiskunnassa nuorempien sukupolvien luontosuhteet ovat kuitenkin polarisoitumassa: osa perheistä ylläpitää monipuolista suhdetta luontoon, kun taas toiset perheet eivät juurikaan liiku luonnossa.

Samaan aikaan tietoisuus luonnossa vietetyn ajan terveyshyödyistä on kasvanut ja lähiluonnossa liikkumisen hyödyistä puhutaan laajasti. Luonnossa oleskelun on todettu muun muassa parantavan itsetuntoa ja mielialaa, vähentävän vihantunnetta sekä vaikuttavan myönteisesti tunteisiin ja käyttäytymiseen (Kaplan, 2001; Kuo \& Sullivan, 2001; Maller, 2009). Lisäksi luontokontaktit vähentävät stressiä, lisäävät ongelmanratkaisu- ja keskittymiskykyä sekä parantavat elimistön puolustusjärjestelmän toimintaa (Hanski ym., 2012; Tyrväinen ym., 2014; van den Berg, Koole, \& van der Wulp, 2003).

Luonnon hyvinvointi- ja terveyshyödyistä käytävässä keskustelussa tulisi jatkossa huomioida luontosuhteiden dynaamisuus. Luontosuhteen kehittyminen edellyttää sekä aikaa että paikkoja luonnon kohtaamiselle - eli mahdollisuuksia harjaantua taitavaksi luonnossa liikkujaksi. Tulevaisuuden kannalta olennaisia ovat erityisesti lasten, nuorten ja lapsiperheiden luontosuhteet. Jotta lähiluonnossa liikkumisen perinnettä voitaisiin hyödyntää lähimatkailua kehitettäessä, meidän tulee ymmärtää paremmin moninaisia luontoyhteyksiä kaupungistuneessa yhteiskunnassa.

Tarkastelimme tutkimuksessamme suomalaisten lasten, nuorten ja perheiden erilaisia tapoja olla yhteyksissä luonnon kanssa ja kokea hyvinvointia luonnossa (Rantala \& Puhakka, tulossa). Tutkimusaineisto koostui 15-21-vuotiaiden nuorten luonnon virkistyskäyttöä koskevista temaattisista kirjoituksista sekä retkeilyä koskevasta etnografisesta aineistosta. 
Tutkimuksen taustalla vaikuttaa ajatus luontosuhteiden relationaalisuudesta: se, miten lapsi tai nuori on yhteyksissä luontoon, on sidoksissa siihen, paljonko hän viettää aikaa luonnossa. Luonnossa olemisen taidot - esimerkiksi taito pukeutua vuodenajan mukaan, liikkua erilaisissa maastoissa, keksiä tekemistä luonnossa ja nähdä luonnon yksityiskohtia - kehittyvät viettämällä aikaa luonnossa. Käytimme tarjouman käsitettä (Gibson, 1979) analyyttisena työvälineenä relationaalisten luontosuhteiden tarkastelussa ja analyysissa. Viimeaikaisissa (yhteiskuntatieteellisissä ja ihmismaantieteellisissä) tutkimuksissa on sovellettu Tim Ingoldin (2000) tapaa nähdä tarjouman ja tarjoumaa havainnoivan ihmisen välinen vuorovaikutus dynaamisena kehkeytymisen prosessina. Tällöin huomio kiinnittyy havainnointiprosessin kehollisuuteen ja aistimellisuuteen, prosessissa harjaantumiseen sekä prosessiin liittyvään hiljaiseen tietoon (Ingold, 2000, s. 11-12). Aineiston analyysissa painotimme relationaalista lähestymistapaa tarjoumiin tarkastelemalla niin nuoria ja lapsiperheitä kuin luontoympäristöjä aktiivisina toimijoina sekä luontosuhteita kehkeytymisen prosesseina (ks. Rautio, 2013).

Tulosten mukaan suomalaiset lapset ja nuoret käyttävät luontoa monipuolisesti virkistäytymiseen. Luontoympäristöt tarjoavat nuorille mahdollisuuden tavata ystäviä, mutta luonnosta haetaan myös yksityisyyden ja vapauden kokemuksia. Pidemmät luonnossa vietettävät ajat esimerkiksi telttaillen tai mökkeillen mahdollistavat intensiivisen yhdessäolon, kun ollaan tiiviissä kanssakäymisessä sekä perheen että ympäröivän luonnon kanssa. Yhdessäolo voi lisätä tietoisuutta vuodenaikojen ja sään vaikutuksesta omaan toimintaan ja olemiseen sekä auttaa huomioimaan läheisiä ihmisiä uusin tavoin.

Luonnossa rauhoitutaan ja päästään pois arkielämän paineista; luontoympäristöt voivat myös vahvistaa nuorten itsetuntoa ja luoda uskoa tulevaisuuteen. Luontoympäristöt tarjoavatkin lapsille, nuorille ja perheille tilan ilmaista erilaisia tunteita ja testata erilaisia toimintatapoja. Asioita voidaan esimerkiksi tehdä hitaammin, aikaa voidaan viettää ilman puhelimia ja tietokoneita ja toimeen tullaan niillä tavaroilla, jotka ovat käsillä. Kaikki tämä edistää hyvinvointia.

Oma merkityksensä on myös luonnon materiaalisilla järjestyksillä eli esimerkiksi sillä, millaista luontoa lasten ja nuorten lähiympäristössä on. Tulosten mukaan nuoret liikkuvat mieluiten metsissä ja rannoilla, mutta myös mökkiympäristö on monille tärkeä luontosuhteen vahvistamisen paikka. Vuodenajat ja säätilat vaikuttavat merkittävästi siihen, millaisia mahdollisuuksia erilaisiin toimintoihin lapset ja nuoret havainnoivat. Vuodenajat ja säätilat nousivat esille erityisesti retkeilyyn liittyvässä etnografisessa aineistossa: ne mahdollistavat erilaisten taitojen kehittämisen ja luontosuhteessa harjaantumisen. Kun esimerkiksi telttaillessa säätä ei pääse pakoon, tulee kehittää taitoja eri säätiloissa toimimiseen.

Isovanhempien ja vanhempien rooli opastajina luonnossa liikkumisen tapoihin nousi niin ikään esille aineistoissa ja ilmentää sitä, miten relationaalinen luontosuhde kiinnittyy lapsen ja nuoren omaan elinympäristöön ja elintapaan. Lapset ja nuoret oppivat jatkuvasti uusia toimintatapoja, ja taitojen kehittymisen sekä luonnossa liikkumiseen harjaantumisen kautta hyvinvointiin liittyvien mahdollisuuksien skaala laajenee. Mitä enemmän vietetään aikaa luonnossa, sitä paremmin opitaan havaitsemaan hyvinvointia lisääviä tarjoumia. Tämä vaikuttaa merkittävästi myös aikuisiän luontosuhteeseen. 
Luonnon virkistyskäytön ylläpitämiseksi ja lähimatkailun edistämiseksi tulisi jatkossa kiinnittää huomiota siihen, miten lasten ja nuorten taidokkuutta toimia erilaisissa luontoympäristöissä voidaan tukea. Erilaisten luontoympäristöjen saavutettavuus ja luonnossa liikkumisen taitoihin opastaminen päiväkodeissa, kouluissa ja harrastustoiminnassa ovat asioita, joita tulisi korostaa suomalaisessa yhteiskunnassa. Lisäksi tulisi pohtia, miten erilaisia perheitä voidaan tukea ja rohkaista liikkumaan lähiluonnossa sekä auttaa perheitä tiedostamaan esimerkiksi mökillä vietetyn ajan merkittävä rooli luontosuhteen ylläpitäjänä.

Mahdollisuudet harjaantua toimimaan luonnossa vaihtuvissa olosuhteissa ovat tärkeitä muuttuvien sää- ja ilmasto-olosuhteiden vuoksi. Sopeutuminen muuttuviin olosuhteisiin ja uusien luonnossa toimimisen tapojen kehittäminen ovat pitkällä aikavälillä kestävämpiä ratkaisuja kuin esimerkiksi laskettelurinteiden ja hiihtolatujen lumettaminen. Taitojen harjaannuttamisen merkittäviä paikkoja ovat etenkin luonnontilaiset ja luonnoltaan monimuotoiset ympäristöt. Rakennettujen puistojen ohella myös kaupunkialueiden lähiluonnosta tulisikin löytyä ympäristöjä, jotka ohjatun toiminnan sijaan houkuttelevat lapsia ja nuoria vapaaseen olemiseen ja leikkimiseen luonnossa.

Kauempana asutuskeskuksista sijaitsevien luontokohteiden, kuten kansallispuistojen, tulisi olla saavutettavissa myös julkisin kulkuvälinein. Aiemmassa tutkimuksessa on havaittu luonnonympäristössä yöpymisen voimistavan kokemusta hyvinvoinnista ja saavan aikaan mieleenpainuvampia kokemuksia (Puhakka, Pitkänen \& Siikamäki, 2017).

Tutkimuksemme tulokset osoittavat, että lähimatkailun edistämiseksi Suomessa tulisi kiinnittää huomiota siihen, kuinka lapsia ja nuoria voidaan kannustaa harjaantumaan aktiivisiksi luonnossa toimijoiksi ja kuinka heidän luontosuhteiden kehkeytymisen prosessejaan voidaan tukea. Erilaisten luontoympäristöjen säilymisen ja saavutettavuuden takaaminen luovat pohjan, jonka varaan lähimatkailua voidaan tulevaisuudessa kehittää.

\section{Lähteet}

Gibson, J. (1979). The ecological approach to visual perception. Boston: Houghton Mifflin.

Hanski, I., von Hertzen, L., Fyhrquist, N., Koskinen, K., Torppa, K., Laatikainen, T., ...Haahtela, T. (2012). Environmental biodiversity, human microbiota, and allergy are interrelated. PNAS, 109, 8334-8339. https://doi.org/10.1073/pnas.1205624109

Ingold, T. (2000). The perception of the environment: Essays on livelihood, dwelling and skill. London: Routledge.

Kaplan, R. (2001). The nature of the view from home. Environment and Behavior, 33, 507-542. https://doi.org/10.1177/00139160121973115

Kuo, F. E. \& Sullivan, W. C. (2001). Aggression and violence in the inner city: Effects of environment via mental fatigue. Environment and Behavior, 33, 543-571. https://doi. org/10.1177/00139160121973124

Maller, C. J. (2009). Promoting children's mental, emotional and social health through contact with nature: A model. Health Education, 109, 522-543. https://doi. org/10.1108/09654280911001185 
Puhakka, R., Pitkänen, K. \& Siikamäki, P. (2017). The health and well-being impacts of protected areas in Finland. Journal of Sustainable Tourism, 25, 1830-47. https://doi.org/10.1080/09669582. 2016.1243696

Rantala, O. \& Puhakka, R. (tulossa). Engaging with nature: Nature affords well-being for families and young people in Finland. Children's Geographies.

Rautio, P. (2013). Children who carry stones in their pockets: On autotelic material practices in everyday life. Children's Geographies, 11, 394-408. https://doi.org/10.1080/14733285.2013.812278

Sievänen, T. \& Neuvonen, M. (2011). Luonnon virkistyskäyttö 2010. (Metlan työraportteja 212.) http://www.metla.fi/julkaisut/workingpapers/2011/mwp212.pdf

Tyrväinen, L., Ojala, A., Korpela, K., Lanki, T., Tsunetsugu, Y. \& Kagawa, T. (2014). The influence of urban green environments on stress relief measures: A field experiment. Journal of Environmental Psychology, 38, 1-9. https://doi.org/10.1016/j.jenvp.2013.12.005

van den Berg, A. E., Koole, S. L. \& van der Wulp, N. Y. (2003). Environmental preference and restoration: (How) are they related? Journal of Environmental Psychology, 23, 135-146. https://doi. org/10.1016/S0272-4944(02)00111-1 